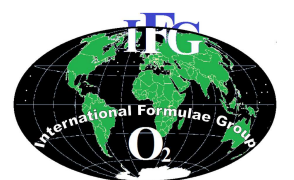

\title{
Use of foliar and stem anatomical characters in the identification of Ludwigia (Linn.) species in Nigeria
}

\author{
A. E. FOLORUNSO*, K. F. ADELALU and Matthew OZIEGBE \\ Department of Botany, Faculty of Science, Obafemi Awolowo University, Ile-Ife, Nigeria. \\ *Corresponding author; E-mail: afolorun@oauife.edu.ng; Tel.: +234 8035068602
}

\begin{abstract}
Foliar and stem anatomical characters that could be used for the identification of nine species of Ludwigia L. viz., Ludwigia abyssinica A. Rich., L. adscendens subsp. diffusa (Forssk)., L. decurrens variety A Walter., L. decurrens variety B Walter., L. erecta (Linn.) Hara, L. hyssopifolia (G.Don) Exell., L. leptocarpa (Nutt.), L. octovalvis variety brevisepala (Jacq.) Raven and L. octovalvis variety linearis (Jacq.) Raven in Nigeria are reported. This is envisaged to facilitate the management of these Ludwigia species; most importantly the invasive species and also to reduce the fluctuations in their taxonomic classifications. Fresh leaves and matured stem of these nine (9) species of Ludwigia from South-western Nigeria were subjected to anatomical study under Light Microscope. The occurrence of hypoamphistomatic stomata and several other stomata types such as anomocytic, staurocytic, anisocytic, cyclocytic and laterocytic in these advanced species of Ludwigia could be responsible for their invasiveness in the environments. Similarly, the mean vessel diameter in Ludwigia species studied represents invasive character; the species with higher mean vessel diameter are likely to be more invasive in their habits. Baseline information on the stem anatomy of the Ludwigia species has been provided; in addition, diagnostic characters for easy identification and classification of the taxa are also reported. The leaf and stem anatomical characters in the Ludwigia species are constant despite their environmental plasticity.
\end{abstract}

() 2014 International Formulae Group. All rights reserved.

Keywords: Ludwigia, epidermal, stomata, morphology, diagnostic, invasive.

\section{INTRODUCTION}

Reports from literature tag Ludwigia as an invasive species, they are known to be invasive in most parts of the world, serving as a threat to native plant species and blocking navigational channels (Oziegbe and Faluyi, 2011). An introduced species becomes a 'transformer invader' when its development produces serious ecological and economic problems (Richardson et al., 2000). The main consequence on ecosystems is the decline of native species, or even the extinction of rare and vulnerable taxa (Burke and Grime, 1996). A set of advantageous biological traits characterizes most invasive plants: competitive life strategy (Pysek et al., 2012), large ecological tolerance, vegetative growth, fast growth, longevity, high seed production, good germination, plasticity of breeding systems, allelopathy, photosynthesis in $\mathrm{C} 4$ and polyploidy (Verlaque et al., 2002). All these assets are rarely found together on a given 
plant species, but the presence of one or two among them can sometimes be sufficient (Muller, 2002). However, the alien Ludwigia taxa possess most of these characters, which might explain their expansion in Nigeria and their classification among the 200 most aggressive world plant invaders (Oziegbe et al., 2010). Six month old seeds of Ludwigia species are more likely to contribute to plant populations than the freshly shed seeds germination media investigated. Also, the production of high number of seeds, enable them to compete and adapt in different ecological conditions (Oziegbe et al., 2011).

The management of these invasive species requires their precise identification, but this appears to be extremely complex (Dandelot et al., 2005). Dutartre et al. (2004) reported that Ludwigia species are phenotypically plastic, such that their growth forms vary under different environmental conditions, which often complicates species identification and has led to a number of fluctuations in their taxonomic classifications. Moreover, the anatomical characteristics of Ludwigia are sparingly mentioned in the general account of Metcalfe and Chalk (1979) and earlier reports on the foliar epidermal morphology and stem anatomy of the genus elsewhere in West Africa are lacking.

In this study, foliar and stem anatomical characters of Ludwigia species were studied to report taxonomic and diagnostic characters which could probably be used for their identification; characters that may be responsible for their invasiveness will also be reported.

\section{MATERIALS AND METHODS Collection of specimen}

Fresh leaves of nine (9) species of Ludwigia common to Nigeria in the family Onagraceae were collected from the Southwestern Nigeria (Table 1). Figure 1 shows the morphological habits of the Ludwigia species studied. The altitudes and geographical coordinates of the localities were taken using a GPS device. Species identification and confirmation was done at the Herbarium of Obafemi Awolowo University Campus (IFE) and Forestry Research Institute of Nigeria Herbarium (FHI), Ibadan.

\section{Foliar anatomical study}

Portions of the leaves were taken from the median part (midway between the tip and the base) from ten accessions of each species. These were put into Jeffrey's maceration mixture (10\% chromic acid and concentrated hydrochloric acid) and kept in oven at $60^{\circ} \mathrm{C}$ for about 15 minutes. Each sample was then washed thoroughly in 5 changes of water. The adaxial and abaxial epidermis was separated by means of dissecting needle and forceps. The epidermal surfaces were stained in $1 \%$ safranin $\mathrm{O}$ for about five minutes, washed with 4 changes of water to remove excess stain and then temporary mounts were made in $25 \%$ glycerol. Stomatal index was calculated according to Dilcher (1974).

\section{Stem anatomical study}

For the stem anatomical study, fine sections (8 $\mu \mathrm{m}-15 \mu \mathrm{m}$ thick) of the transverse sections, tangential longitudinal sections, and radial longitudinal section, were done using a Reichert microtome. The sections for the stem were stained with $1 \%$ aqueous solution of safranin " $O$ " and counter stained with $1 \%$ aqueous solution of alcian blue and mounted in $25 \%$ glycerine on clean glass slide for microscopic studies. Quantitative characters of the stem were measured with the aid of an ocular micrometer inserted in the eyepiece of the microscope. These measurements were later multiplied by the ocular constant with respect to the power under which they were taken and photomicrographs of the slides were taken with Leitz camera mounted on Dialux Research Microscope.

\section{RESULTS}

\section{Ludwigia abyssinica A. Rich.}

The abaxial epidermal cells are irregular with sinuous to undulating anticlinal 
wall and the periclinal wall is smooth (Figure 2). The epidermal cells are $22.5 \mu \mathrm{m}-47.5 \mu \mathrm{m}$ long and $10.0 \mu \mathrm{m}-25.0 \mu \mathrm{m}$ broad. Stomata being anomocytic are elliptical in shape, size ranges between $17.5 \mu \mathrm{m}-27.5 \mu \mathrm{m}$ long and $12.5 \mu \mathrm{m}-17.5 \mu \mathrm{m}$ broad, the stomata index is $28.9 \%$ (Figure 2). Trichomes are simple and non glandular. Styloids are present. On the adaxial surface, the epidermal cells are irregular with straight to undulating anticlinal wall and the periclinal wall is smooth. The epidermal cell size ranges from $25.0 \mu \mathrm{m}-$ $60.0 \mu \mathrm{m}$ long and $15 \mu \mathrm{m}-27.5 \mu \mathrm{m}$ broad. Anisocytic and staurocytic stomata are present, they are elliptical in shape and their size ranges between $20.0 \mu \mathrm{m}-25.0 \mu \mathrm{m}$ long and $12.5 \mu \mathrm{m}-27.5 \mu \mathrm{m}$ in broad, the stomata index is $6.8 \%$ (Figure 2). Trichomes are simple and non glandular.

The stem is diffuse porous, vessels are predominantly solitary and sometimes in radial multiple, pore chains are present (Figure 3). Vessel shape varies from elliptic to circular to angular in cross section and the mean vessel diameter is $67.5 \mu \mathrm{m}$. Starch grains are present within the paratracheal parenchyma cells. The rays are upright, largely uniseriate, heterocellular and non storied. Ray length varies from $58.0 \mu \mathrm{m}-$ $198.0 \mu \mathrm{m}$ (Figure 3).

\section{L. adscendens subsp. diffusa (Forssk)}

The abaxial epidermal cells are irregular with sinuous to undulating anticlinal wall and the periclinal wall is smooth (Figure 2). The epidermal cells are $25.0 \mu \mathrm{m}-52.5 \mu \mathrm{m}$ long and $10.0 \mu \mathrm{m}-25.0 \mu \mathrm{m}$ broad. Stomata types are anomocytic and staurocytic, they are elliptical in shape, size ranges between 17.5 $\mu \mathrm{m}-25.0 \mu \mathrm{m}$ long and $10.0 \mu \mathrm{m}-15.0 \mu \mathrm{m}$ broad, the stomata index is $9.9 \%$ (Figure 2). Trichomes are simple non glandular. Raphides are present. On the adaxial surface, the epidermal cells are irregular with sinuous to undulating anticlinal wall and the periclinal wall is smooth. The epidermal cell size ranges from $25.0 \mu \mathrm{m}-52.5 \mu \mathrm{m}$ long and 10.0 $\mu \mathrm{m}-25.0 \mu \mathrm{m}$ broad. The stomata is anomocytic, they are elliptical in shape and their size ranges between $20.0 \mu \mathrm{m}-22.5 \mu \mathrm{m}$ long and $12.5 \mu \mathrm{m}-15.0 \mu \mathrm{m}$ in broad, the stomata index is $11.0 \%$ (Figure 2). Trichomes are simple and non glandular, prismatic crystals are present.

The stem is diffuse porous, vessels are majorly solitary and sometimes radial multiple, pore chains present (Figure 3). Vessel shape varies from elliptic to circular in cross section; the mean vessel diameter is $\mathbf{5 8 . 0}$ $\mu \mathrm{m}$. The paratracheal parenchyma cells within the pith are occupied with starch grains. The stem shows uniseriate rays with adjourning vessel elements. The rays are upright, non storied and heterocellular in nature. The ray length varies from $37.0 \mu \mathrm{m}-84.0 \mu \mathrm{m}$. There are tracheid fibres and square cells across the stem (Figure 3).

\section{L. decurrens variety A Walter}

The abaxial epidermal cells are irregular with straight to undulating anticlinal wall, the periclinal wall is smooth (Figure 2). The epidermal cells are $27.5 \mu \mathrm{m}-57.5 \mu \mathrm{m}$ long and $7.5 \mu \mathrm{m}-30.0 \mu \mathrm{m}$ broad. Stomata being anomocytic are elliptical in shape, size ranges between $12.5 \mu \mathrm{m}-22.5 \mu \mathrm{m}$ long and $7.5 \mu \mathrm{m}-15.0 \mu \mathrm{m}$ broad, the stomata index is $29.1 \%$ (Figure 2). Scale trichome is present. On the adaxial surface, the epidermal cells are irregular with wavy to undulating anticlinal wall, the periclinal wall is smooth. The epidermal cell size ranges from $32.5 \mu \mathrm{m}-$ $62.5 \mu \mathrm{m}$ long and $12.5 \mu \mathrm{m}-25.0 \mu \mathrm{m}$ broad. Anisocytic, laterocytic and staurocytic stomata are present, they are elliptical in shape and their size ranges between $12.5 \mu \mathrm{m}-$ $22.5 \mu \mathrm{m}$ long and $7.5 \mu \mathrm{m}-15.0 \mu \mathrm{m}$ in broad, the stomata index is $13.4 \%$ (Figure 2). Prismatic crystals and styloids are present.

Stem is diffuse porous, solitary vessels are predominant with few pore chains across the section, vessel pores vary from circular to elliptic in shape (Figure 3). The mean vessel diameter is $92.8 \mu \mathrm{m}$. Parenchyma cells are paratracheal and polygonal. Raphides and medullary bundles are present within the parenchyma cells in pith. The rays are upright, largely uniseriate, heterocellular and non - 
storied. The ray length varies from $32.0 \mu \mathrm{m}-$ $110.0 \mu \mathrm{m}$ (Figure 3). There are tracheid fibres across the stem.

\section{L. decurrens variety B Walter}

The abaxial epidermal cells are irregular with sinuous to undulating anticlinal wall, the periclinal wall is smooth (Figure 2). The epidermal cells are $30.0 \mu \mathrm{m}-65.0 \mu \mathrm{m}$ long and $12.5 \mu \mathrm{m}-30.0 \mu \mathrm{m}$ broad. Stomata being anomocytic, are elliptical in shape, size ranges between $15.0 \mu \mathrm{m}-25.0 \mu \mathrm{m}$ long and $10.0 \mu \mathrm{m}-15.0 \mu \mathrm{m}$ broad, the stomata index is $23.8 \%$ (Figure 2). Starch grains are present. On the adaxial surface, the epidermal cells are irregular with wavy to undulating anticlinal wall, the periclinal wall is smooth. The epidermal cell size ranges from $25.0 \mu \mathrm{m}-$ $60.0 \mu \mathrm{m}$ long and $10.0 \mu \mathrm{m}-42.5 \mu \mathrm{m}$ broad. Anomocytic stomata is present, they are elliptical in shape and their size ranges between $12.5 \mu \mathrm{m}-25.0 \mu \mathrm{m}$ long and $10.0 \mu \mathrm{m}$ - $15.0 \mu \mathrm{m}$ in broad, the stomata index is $10.7 \%$ (Figure 2). Starch grains are present with scale trichome.

Stem is diffuse porous, vessels are predominantly solitary and sometimes cluster, pore chains are present (Figure 3). Vessel shape varies from elliptic to circular to angular in cross section; the mean vessel diameter is $81.0 \mu \mathrm{m}$. Paratracheal parenchyma cells are abundant. Starch grains occupied the pith and medullary bundles are present within the pith. The stem shows both uniseriate rays and biseriate rays with adjourning tracheid elements. The rays are non - storied, the cells of the rays are homocellular in uniseriate rays and heterocellular in biseriate rays. The ray length varies from $37.0 \mu \mathrm{m}-98.0 \mu \mathrm{m}$ (Figure 3). There are tracheid fibres across the stem. The stem is majorly made up of upright ray cells that are heterogeneous in nature with some few square ray cells. There are also tracheids fibres across the section.

\section{L. erecta (Linn.) Hara}

The abaxial epidermal cells are irregular with sinuous to undulating anticlinal wall, the periclinal wall is smooth (Figure 2). The epidermal cells are $32.5 \mu \mathrm{m}-70.0 \mu \mathrm{m}$ long and $12.5 \mu \mathrm{m}-25.0 \mu \mathrm{m}$ broad. Stomata being staurocytic, are elliptical in shape, size ranges between $12.5 \mu \mathrm{m}-30 \mu \mathrm{m}$ long and 7.5 $\mu \mathrm{m}-15 \mu \mathrm{m}$ broad, the stomata index is $27.9 \%$ (Figure 2). Trichomes are simple non glandular. Raphides are present. On the adaxial surface, the epidermal cells are irregular with sinuous to undulating anticlinal wall, the periclinal wall is smooth. The epidermal cell size ranges from $25.0 \mu \mathrm{m}-$ $70.0 \mu \mathrm{m}$ long and $10 \mu \mathrm{m}-30.0 \mu \mathrm{m}$ broad. Anomocytic stomata is present, they are elliptical in shape and their size ranges between $15.0 \mu \mathrm{m}-25.0 \mu \mathrm{m}$ long and $10.0 \mu \mathrm{m}$ - $15.0 \mu \mathrm{m}$ in broad, the stomata index is $17.1 \%$ (Figure 2). Raphides and starch grains are present.

Stem is diffuse porous, and made up of both solitary and multiple vessels, their shapes vary from circular to elliptic and sometime angular across the section (Figure 3). The mean vessel diameter is $85.5 \mu \mathrm{m}$. Paratracheal parenchyma cells are abundant. The stem shows both uniseriate rays and biseriate rays with adjourning tracheid elements. The rays are upright, non - storied, homocellular in uniseriate rays and heterocellular in biseriate rays. The ray length varies from $33.0 \mu \mathrm{m}-$ $125.0 \mu \mathrm{m}$ (Figure 3). There are tracheid fibres across the stem.

\section{L. hyssopifolia (G.Don) Exell}

The abaxial epidermal cells are irregular with sinuous to undulating anticlinal wall, the periclinal wall is smooth (Figure 2). The epidermal cells are $25.5 \mu \mathrm{m}-55.0 \mu \mathrm{m}$ long and $10.0 \mu \mathrm{m}-45.0 \mu \mathrm{m}$ broad. Stomata being anomocytic, are elliptical in shape, size ranges between $12.5 \mu \mathrm{m}-25.0 \mu \mathrm{m}$ long and $10.0 \mu \mathrm{m}-15 \mu \mathrm{m}$ broad, the stomata index is $31.8 \%$. Styloids are present. On the adaxial surface, the epidermal cells are irregular with sinuous to undulating anticlinal wall, the periclinal wall is smooth (Figure 2). The epidermal cell size ranges from $25.0 \mu \mathrm{m}-$ $70.0 \mu \mathrm{m}$ long and $10 \mu \mathrm{m}-22.5 \mu \mathrm{m}$ broad. Anomocytic stomata is present, they are elliptical in shape and their size ranges between $15.0 \mu \mathrm{m}-22.5 \mu \mathrm{m}$ long and $10.0 \mu \mathrm{m}$ 
$-15.0 \mu \mathrm{m}$ in broad, the stomata index is $16.1 \%$ (Figure 2). Trichomes are simple non glandular.

Stem is diffuse porous, and made up of solitary and sometimes radial multiple vessels, pore chains present (Figure 3). Vessel shape varies from elliptic to circular in cross section; the mean vessel diameter is $58.25 \mu \mathrm{m}$. Paratracheal parenchyma cells are abundant and those within the pith are occupied with some raphides, monohydric crystal, druses and starch grains. The non-storied rays which are uniseriate and biseriate are flanked by tracheid elements. These rays are heterocellular and upright with adjourning tracheid vessel elements and tracheid fibres. The ray length varies from $17 \mu \mathrm{m}-57 \mu \mathrm{m}$ (Figure 3).

\section{L. leptocarpa (Nutt.)}

The abaxial epidermal cells are irregular with sinuous to undulating anticlinal wall, the periclinal wall is smooth (Figure 2). The epidermal cells are $20.0 \mu \mathrm{m}-42.5 \mu \mathrm{m}$ long and $10.0 \mu \mathrm{m}-37.5 \mu \mathrm{m}$ broad. Stomata being anisocytic and staurocytic, are elliptical in shape, size ranges between $17.5 \mu \mathrm{m}-25.0$ $\mu \mathrm{m}$ long and $12.5 \mu \mathrm{m}-20.0 \mu \mathrm{m}$ broad, the stomata index is $18.6 \%$ (Figure 2). Trichomes are simple non glandular. On the adaxial surface, the epidermal cells are irregular with straight to sinuous to undulating anticlinal wall, the periclinal wall is smooth. The epidermal cell size ranges from $20.0 \mu \mathrm{m}-$ $47.50 \mu \mathrm{m}$ long and $10.0 \mu \mathrm{m}-25.0 \mu \mathrm{m}$ broad. Anomocytic stomata is present, they are elliptical in shape and their size ranges between $17.5 \mu \mathrm{m}-25.0 \mu \mathrm{m}$ long and $12.5 \mu \mathrm{m}$ $-15.0 \mu \mathrm{m}$ in broad, the stomata index is $1.8 \%$ (Figure 2). Both non glandular unicellular and non glandular multicellular trichomes are present and numerous.

Stem is diffuse porous, vessels are predominantly solitary and sometimes cluster, and pore chains are rare (Figure 3). On the epidermis are multicellular non glandular trichomes. Vessel shape varies from elliptic to circular in cross section. The mean vessel diameter is $125.75 \mu \mathrm{m}$. The rays are upright, heterocellular, uniseriate and multiseriate with adjourning tracheal fibres. The rays are non storied with varying cell sizes and the ray length varies from $49 \mu \mathrm{m}-215 \mu \mathrm{m}$ (Figure 3).

\section{(Jacq.) Raven}

L. octovalvis variety brevisepala

The abaxial epidermal cells are irregular vary from straight to sinuous to undulating anticlinal wall, the periclinal wall is striated (Figure 2). The epidermal cells are $25.0 \mu \mathrm{m}-67.5 \mu \mathrm{m}$ long and $10.0 \mu \mathrm{m}-32.5$ $\mu \mathrm{m}$ broad. Stomata being anomocytic and cyclocytic, are elliptical in shape, size ranges between $17.5 \mu \mathrm{m}-50.0 \mu \mathrm{m}$ long and $7.5 \mu \mathrm{m}$ $-52.5 \mu \mathrm{m}$ broad, the stomata index is $23.4 \%$ (Figure 2). Trichomes are simple non glandular. Raphides are present and starch grains are present. On the adaxial surface, the epidermal cells are irregular with straight to undulating anticlinal wall, the periclinal wall is smooth. The epidermal cell size ranges from $22.5 \mu \mathrm{m}-57.50 \mu \mathrm{m}$ long and $12.5 \mu \mathrm{m}-$ $52.5 \mu \mathrm{m}$ broad. Anomocytic and anisocytic stomata are present, they are elliptical in shape and their size ranges between $15.0 \mu \mathrm{m}-$ $27.5 \mu \mathrm{m}$ long and $7.5 \mu \mathrm{m}-17.5 \mu \mathrm{m}$ in broad, the stomata index is $14.8 \%$ (Figure 2). Trichomes are simple non glandular and starch grains are present.

Stem is diffuse porous. On the section are many pore chains and sometime radial multiple vessels, stem is made up of solitary vessels which are not circular but vary from elliptic to angular in shape (Figure 3). The mean vessel diameter is $131.5 \mu \mathrm{m}$. There are uniseriate rays across the section. On the epidermis are multicellular non glandular trichomes. The rays are uniseriate, non-storied and homocellular with adjourning tracheid elements, upright ray cells that are homogeneous in nature, ray length varies from $46 \mu \mathrm{m}-123 \mu \mathrm{m}$ (Figure 3).

\section{L. octovalvis variety linearis (Jacq.) Raven}

The abaxial epidermal cells are irregular varies from sinuous to undulating anticlinal wall, the periclinal wall is striated (Figure 2). The epidermal cells are $25.0 \mu \mathrm{m}-$ $77.5 \mu \mathrm{m}$ long and $12.5 \mu \mathrm{m}-30.0 \mu \mathrm{m}$ broad. Stomata being staurocytic, are elliptical in shape, size ranges between $15.0 \mu \mathrm{m}-25.0 \mu \mathrm{m}$ long and $10.0 \mu \mathrm{m}-15.0 \mu \mathrm{m}$ broad, the stomata index is $25.6 \%$ (Figure 2). Trichomes are simple non glandular. Raphides and starch grains are present. On the adaxial surface, the 
epidermal cells are irregular with sinuous to undulating anticlinal wall, the periclinal wall is smooth. The epidermal cell size ranges from $25.0 \mu \mathrm{m}-72.50 \mu \mathrm{m}$ long and $12.5 \mu \mathrm{m}$ $30.0 \mu \mathrm{m}$ broad. Anomocytic stomata is present, they are elliptical in shape and their size ranges between $15.0 \mu \mathrm{m}-25.0 \mu \mathrm{m}$ long and $10.0 \mu \mathrm{m}-17.5 \mu \mathrm{m}$ in broad, the stomata index is $9.9 \%$ (Figure 2). Trichomes are simple non glandular and starch grains are present.

Stem is diffuse porous, vessels are predominantly solitary and sometimes radial multiple, pore chains rare (Figure 3). Vessel shape varies from elliptic to circular to angular in cross section. The mean vessel diameter is $39.25 \mu \mathrm{m}$. Paratracheal parenchyma cells are abundant. Uniseriate and biseriate rays are present, they are non-storied and heterocellular, which are flanked by tracheid elements and tracheid fibres across the stem. The stem is mainly made up of upright ray cells that are heterogeneous in nature with some few square ray cells. The ray length varies from $75 \mu \mathrm{m}-160 \mu \mathrm{m}$ (Figure 3).
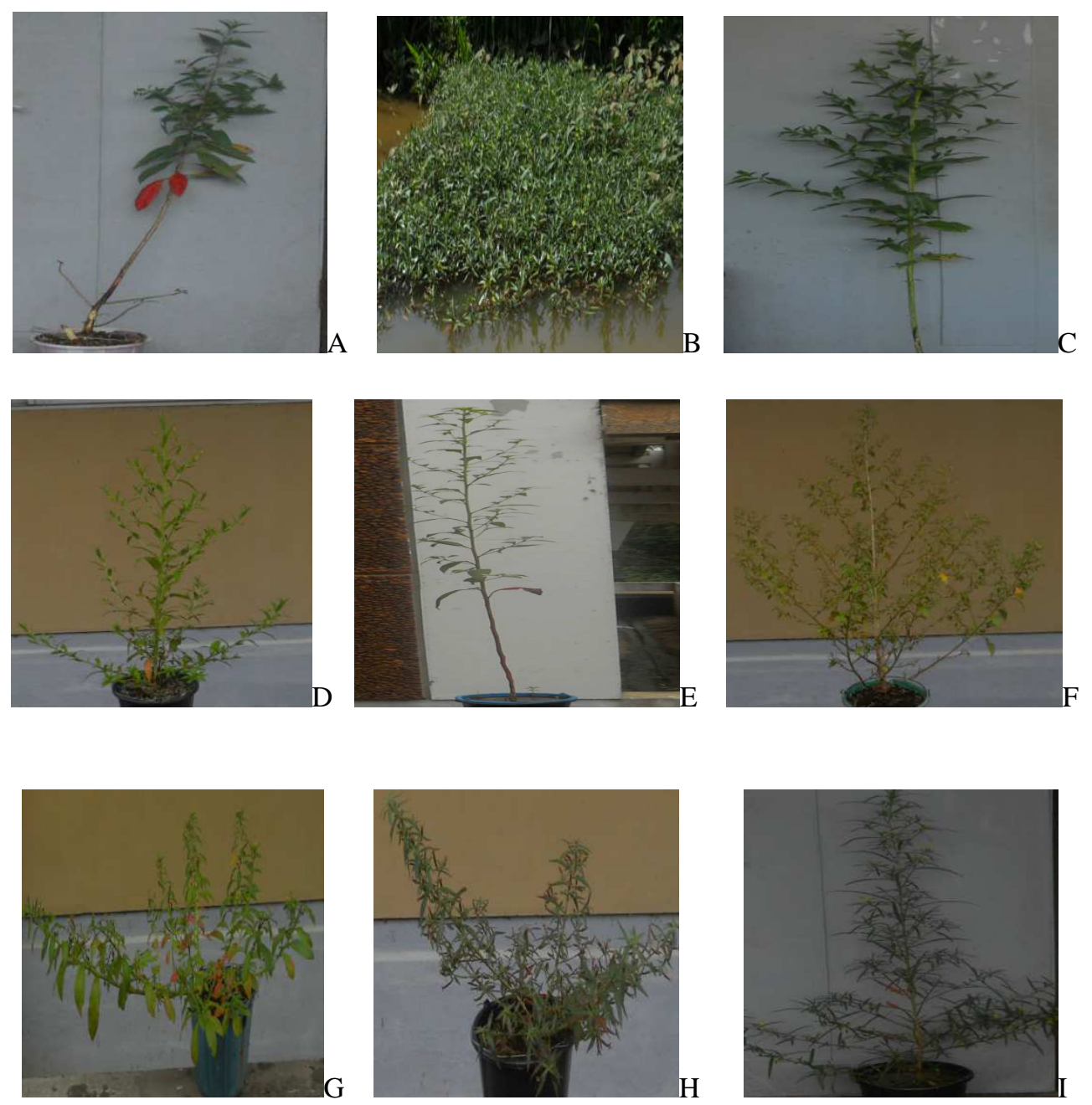

Figure 1: Morphological habits of the Ludwigia species studied. A) L. abyssinica, B) L. adscendens subsp. diffusa, C) L. decurrens A, D) L. decurrens B, E) L. erecta, F) L. hyssopifolia, G) $L$. leptocarpa, H) L. octovalvis variety brevisepala, I) L. octovalvis variety linearis. Scale $=12 \mathrm{~cm}$ 

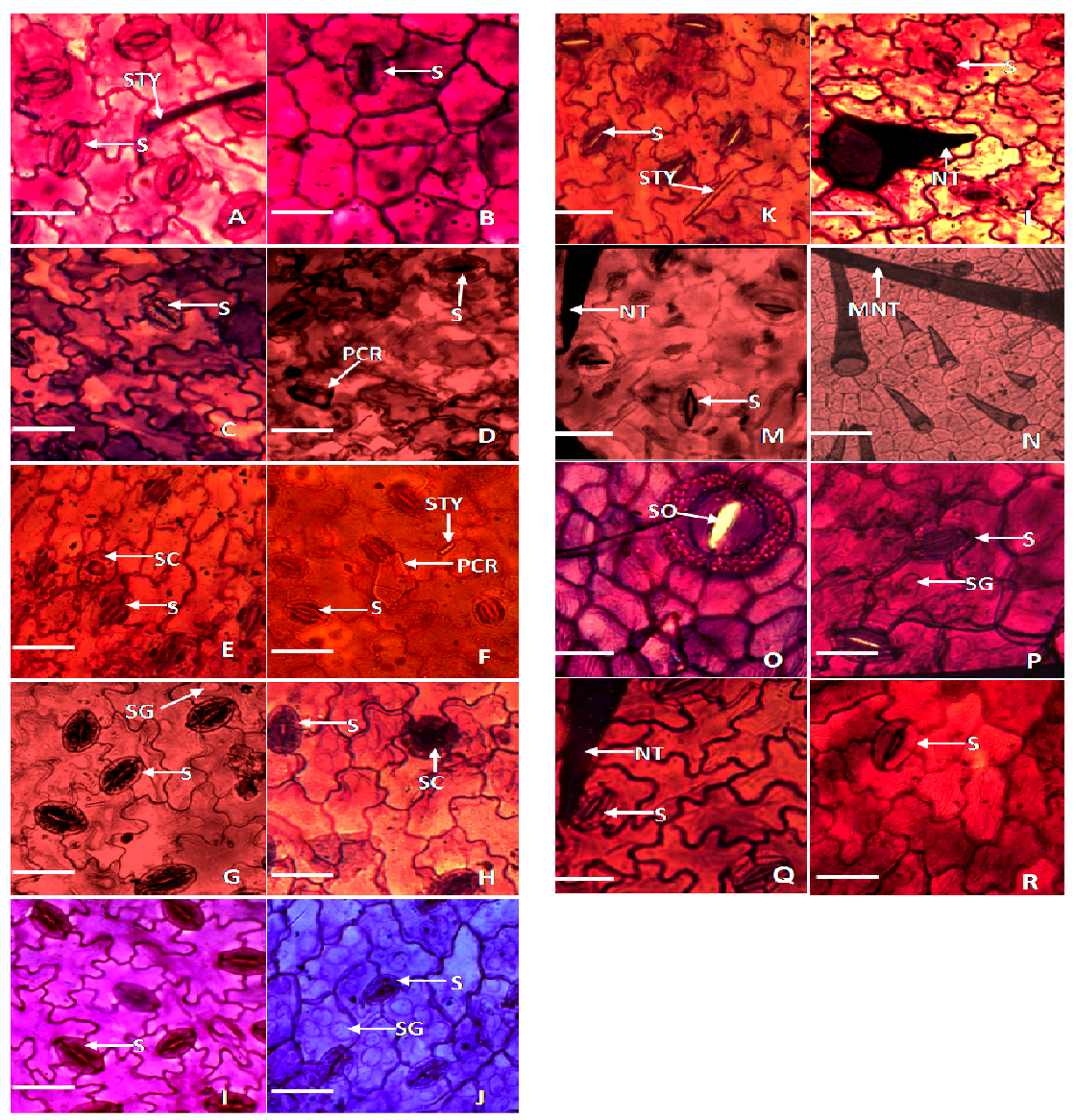

Figure 2: Abaxial and Adaxial epidermal surfaces of Ludwigia species. L. abyssinica, A) abaxial, B) adaxial; L. adscendens subsp. diffusa, C) abaxial, D) adaxial; L. decurrens A, E) abaxial, F) adaxial; L. decurrens $B, \mathrm{G}$ ) abaxial, H) adaxial; L. erecta, I) abaxial, J) adaxial; L. hyssopifolia, K) abaxial, L) adaxial; L. leptocarpa, M) abaxial N) adaxial; L. octovalvis variety brevisepala, O) abaxial, P) adaxial; L. octovalvis variety linearis, Q) abaxial, R) adaxial. Scale $=714 \mu \mathrm{m}$.

\section{DISCUSSION}

The taxonomic values of epidermal features are well documented in literatures, where they have been used to delimit a number of plant taxa (Jayeola et al., 2001; Ogundipe, 2004; Arzani et al., 2013; Folorunso and Awosode, 2013). All the species of Ludwigia studied are hypoamphistomatic and in addition, five stomata types were observed across the species on both the abaxial and adaxial surfaces which are: anomocytic, staurocytic, anisocytic, cyclocytic and laterocytic. This is contrary to the report of Metcalfe and Chalk (1979) and Kadiri and Olowokudejo (2010), which says that the stomata distribution is hypostomatic and that paracytic stomata is the only stomata type present in the family. Anomocytic stomata are common on the adaxial and abaxial surfaces of $L$. decurrens variety B, L. erecta, L. hyssopifolia and L. octovalvis variety linearis. Metcalfe and Chalk, 1979 had earlier reported anomocytic stomata otherwise known as ranunculaceous as the most primitive stomata type. It may therefore be inferred that the species with solely anomocytic stomata on both surface such as $L$. decurrens variety $\mathrm{B}, L$. erecta, $L$. hyssopifolia and L. octovalvis variety linearis are more primitive while the species with 
A. E. FOLORUNSO et al. / Int. J. Biol. Chem. Sci. 2232-2243, 2014
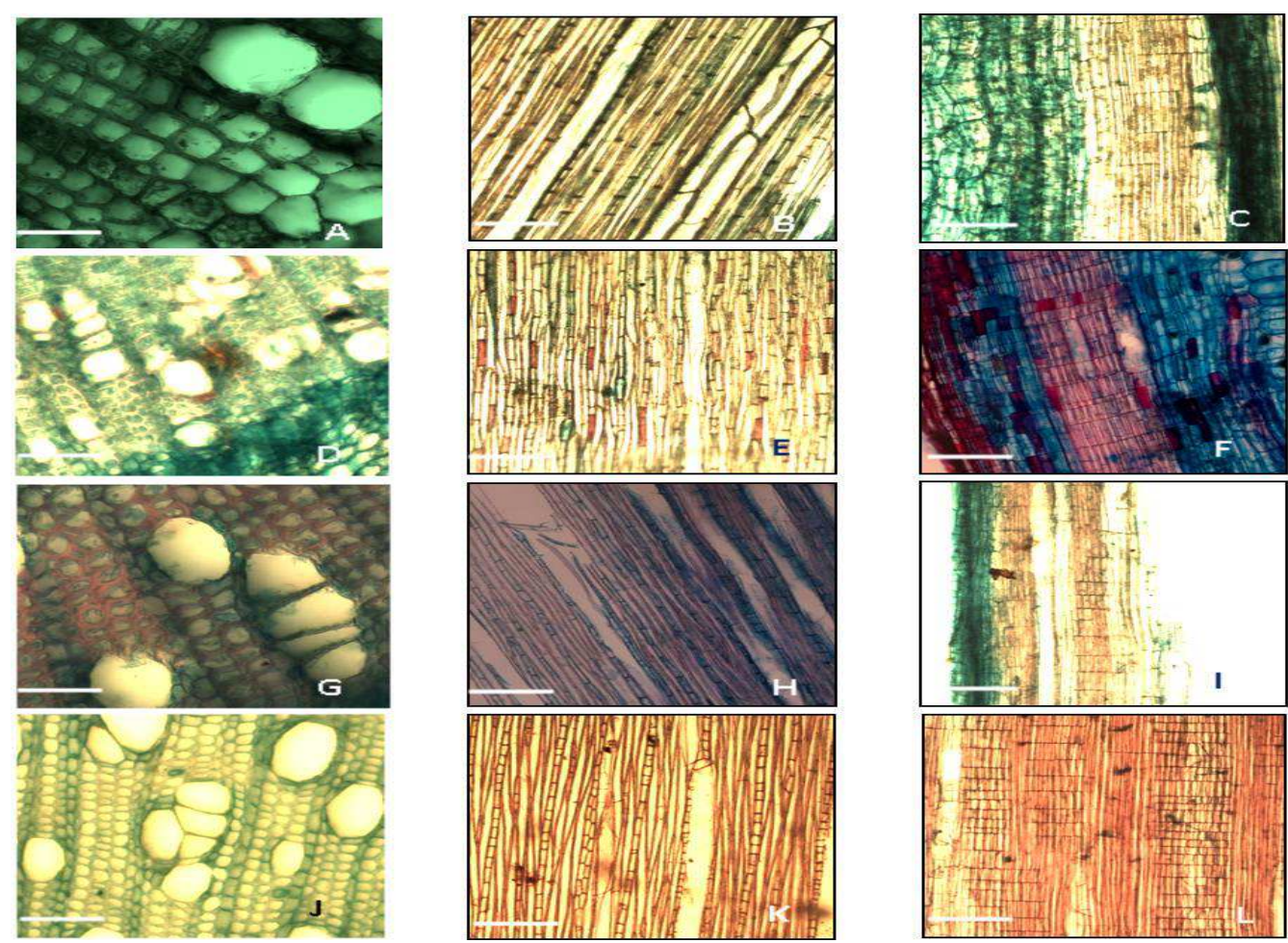

Figure 3: Transverse (TS), Tangential Longitudinal Section (TLS) and Radial Longitudinal Section (RLS) of Ludwigia species. L. abyssinica, A) TS, B) TLS, C) RLS; L. adscendens subsp. diffusa, D) TS, E) TLS, F) RLS; L. decurrens A, G) TS, H) TLS, I) RLS; L. decurrens B, J) TS, K) TLS, L) RLS. Scale $=714 \mu \mathrm{m}$. 

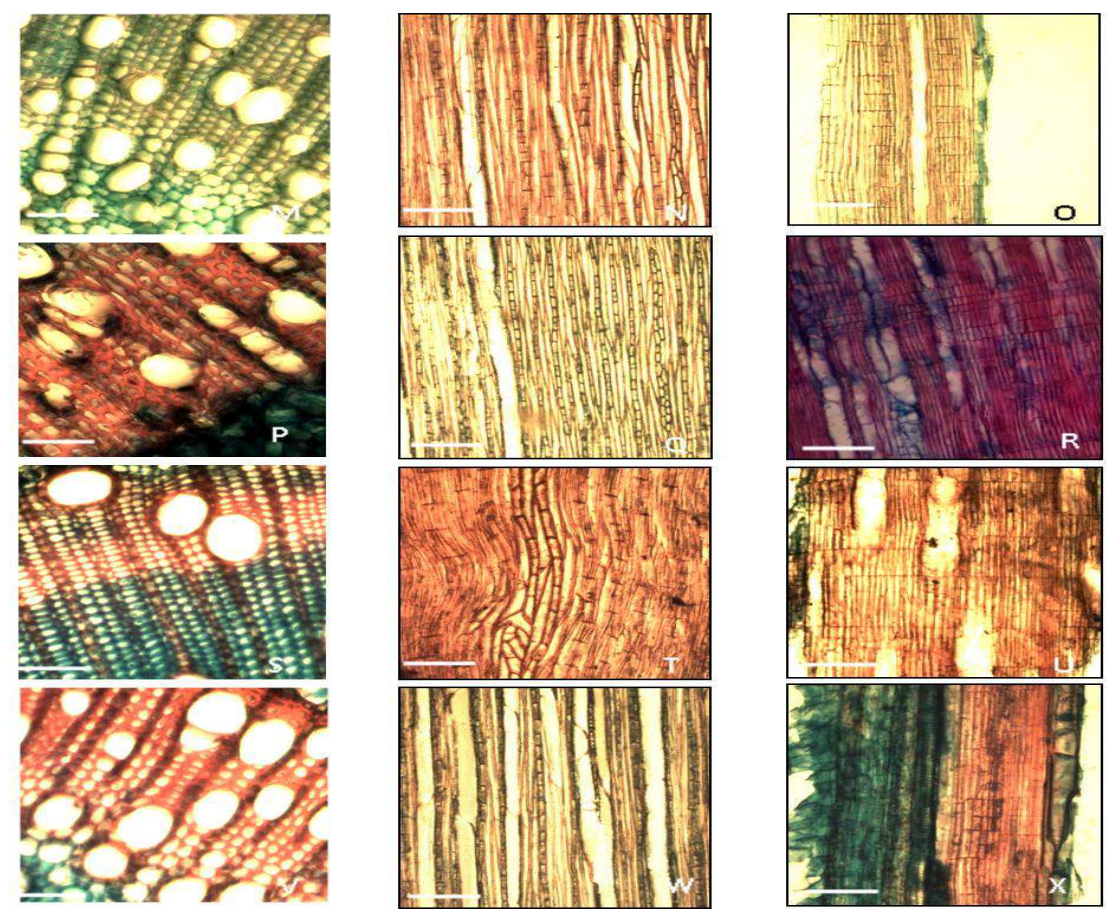

Figure 3 contd: Transverse (TS), Tangential longitudinal section (TLS) and Radial longitudinal section (RLS) of Ludwigia species, L. erecta, M) TS, N) TLS, O) RLS; L. hyssopifolia, P) TS, Q) TLS, R) RLS; L. leptocarpa, S) TS, T) TLS, U) RLS; L. octovalvis variety brevisepala, V) TS, W) TLS, X) RLS. Scale $=714 \mu \mathrm{m}$.
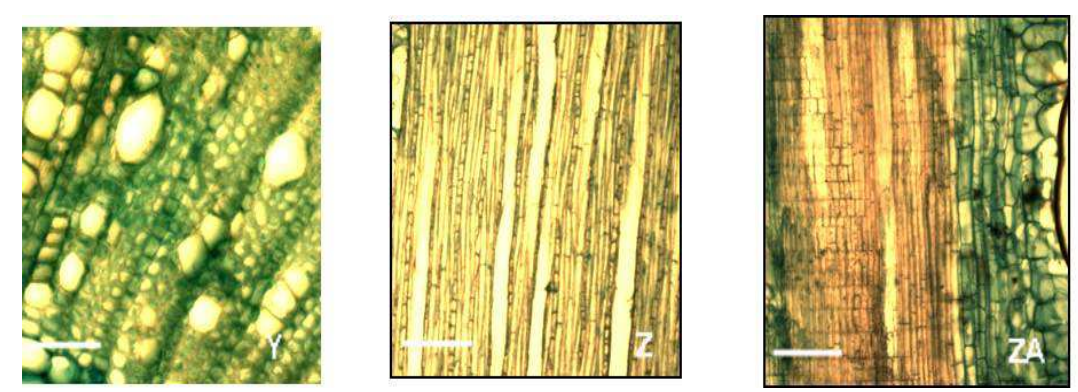

Figure 3 contd: Transverse (TS), Tangential longitudinal section (TLS) and Radial longitudinal section (RLS) of Ludwigia species, L. octovalvis variety linearis, Y) TS, Z) TLS, ZA) RLS. Scale = $714 \mu \mathrm{m}$.

other stomata types probably on either surface of the epidermal layer or on both surfaces of the epidermal layer such as $L$. abyssinica, $L$. adscendens subsp. diffusa, $L$. decurrens A, $L$. leptocarpa and $L$. octovalvis variety brevisepala are already undergoing evolution and therefore are more advanced. The occurrence of hypoamphistomatic stomata and several other stomata types in these advanced species of Ludwigia could be responsible for their invasiveness in the environments. The presence of cyclocytic stomata in Ludwigia octovalvis variety brevisepala delimits it from the other species. Stomata index is generally 
Table 1: A list of Ludwigia species used for the study and their locations.

\begin{tabular}{|c|c|c|}
\hline Species & Location & Coordinates \\
\hline L. abyssinica A. Rich. & Conference Centre, O.A.U. Ile-Ife & $\mathrm{N} 07^{\circ} 31.424$, E $004^{\circ} 31.836,267 \mathrm{~m}$ \\
\hline L. abyssinica A. Rich. & Infinite Grace, O.A.U. Ile- Ife & $\mathrm{N} 07^{\circ} 31.613$, E $004^{\circ} 31.898,272 \mathrm{~m}$ \\
\hline L. abyssinica A. Rich. & Along Anatomy Dept. O.A.U. Ile-Ife & $\mathrm{N} 07^{\circ} 31.097$, E $004^{\circ} 32.546,284 \mathrm{~m}$ \\
\hline L. adscendens ssp. Diffusa (Forssk) & Oke-Ooye, Ilesa & $\mathrm{N} 07^{\circ} 37.068, \mathrm{E} 004^{\circ} 44.756,382 \mathrm{~m}$ \\
\hline L. decurrens variety A Walter & Along Botany Dept. O.A.U. Ile-Ife & $\mathrm{N} 07^{\circ} 31.251$, E $004^{\circ} 31.594,532 \mathrm{~m}$ \\
\hline L. decurrens variety A Walter & Along Botany Dept. O.A.U. Ile-Ife & $\mathrm{N} 07^{\circ} 31.251$, E $004^{\circ} 31.594,620 \mathrm{~m}$ \\
\hline L. decurrens variety A Walter & Along Anatomy Dept. O.A.U. Ile-Ife & $\mathrm{N} 07^{\circ} 28.261$, E $004^{\circ} 31.594,542 \mathrm{~m}$ \\
\hline L. decurrens variety B Walter & Conference Centre, O.A.U. Ile-Ife & 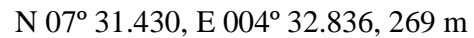 \\
\hline L. decurrens variety B Walter & O.A.U. Ile-Ife Teaching Hospital & $\mathrm{N} 07^{\circ} 31.412$, E $004^{\circ} 34.483,264 \mathrm{~m}$ \\
\hline L. erecta (Linn.) Hara & Oke-Ooye, Ilesha & $\mathrm{N} 07^{\circ} 37.068$, E $004^{\circ} 44.767,379 \mathrm{~m}$ \\
\hline L. erecta (Linn.) Hara & Iloko Ijesha & $\mathrm{N} 07^{\circ} 38.924$, E $004^{\circ} 48.965,386 \mathrm{~m}$ \\
\hline L. erecta (Linn.) Hara & O.A.U. Ile-Ife Teaching Hospital & $\mathrm{N} 07^{\circ} 31.412$, E $004^{\circ} 34.493,244 \mathrm{~m}$ \\
\hline L. erecta (Linn.) Hara & Behind GT Bank O.A.U. Ile-Ife & $\mathrm{N} 07^{\circ} 31.212$, E $004^{\circ} 31.493,244 \mathrm{~m}$ \\
\hline L. hyssopifolia (G.Don) Exell & Oke-Ooye, Ilesha & $\mathrm{N} 07^{\circ} 37.068$, E $004^{\circ} 44.767,379 \mathrm{~m}$ \\
\hline L. hyssopifolia (G.Don) Exell & O.A.U. Ile-Ife Teaching Hospital & $\mathrm{N} 07^{\circ} 31.412$, E $004^{\circ} 34.483,264 \mathrm{~m}$ \\
\hline L. hyssopifolia (G.Don) Exell & Along Anatomy Dept. O.A.U. Ile-Ife & $\mathrm{N} 07^{\circ} 28.261$, E $004^{\circ} 31.594,542 \mathrm{~m}$ \\
\hline L. leptocarpa (Nutt.) & Along Road 7 Area, O.A.U. Ile-Ife & $\mathrm{N} 07^{\circ} 30.787$, E $004^{\circ} 32.924,261 \mathrm{~m}$ \\
\hline L. leptocarpa (Nutt.) & Along Road 7 Area, O.A.U. Ile-Ife & $\mathrm{N} 07^{\circ} 30.787$, E $004^{\circ} 32.924,255 \mathrm{~m}$ \\
\hline L. leptocarpa (Nutt.) & Along Road 7 Area, O.A.U. Ile-Ife & $\mathrm{N} 07^{\circ} 30.787$, E $004^{\circ} 32.924,243 \mathrm{~m}$ \\
\hline L. octovalvis variety brevisepala (Jacq.) Raven & Along Anatomy Dept. O.A.U. Ile-Ife & $\mathrm{N} 07^{\circ} 31.097$, E $004^{\circ} 31.546,280 \mathrm{~m}$ \\
\hline L. octovalvis variety brevisepala (Jacq.) Raven & Infinite Grace, O.A.U. Ile- Ife & $\mathrm{N} 07^{\circ} 31.613$, E $004^{\circ} 31.897,271 \mathrm{~m}$ \\
\hline L. octovalvis variety brevisepala (Jacq.) Raven & O.A.U. Ile-Ife Teaching Hospital & $\mathrm{N} 07^{\circ} 31.417$, E $004^{\circ} 34.483,269 \mathrm{~m}$ \\
\hline L. octovalvis variety linearis (Jacq.) Raven & Along Botany Dept. O.A.U. Ile-Ife & $\mathrm{N} 07^{\circ} 31.251$, E $004^{\circ} 31.594,620 \mathrm{~m}$ \\
\hline L. octovalvis variety linearis (Jacq.) Raven & Oke-Ooye, Ilesa & $\mathrm{N} 07^{\circ} 37.381$, E $004^{\circ} 47.224,392 \mathrm{~m}$ \\
\hline L. octovalvis variety linearis (Jacq.) Raven & Ede Road, Ile-Ife & $\mathrm{N} 07^{\circ} 101.139$, E $004^{\circ} 44.83,377 \mathrm{~m}$ \\
\hline
\end{tabular}


higher on the abaxial surfaces of all the species than on the adaxial surfaces of all the species except in L. adscendens subsp. diffusa, this is the only floating species with inflated roots produced from the nodes. On the abaxial surface, L. hyssopifolia has the highest stomata index and $L$. adscendens subsp. diffusa has the lowest stomata index. However, on the adaxial surface, L. erecta has the highest stomata index while L. leptocarpa has the lowest. The presence of styloids in $L$. abyssinica, L. decurrens A and L. hyssopifolia is significant, these are the species with highest stomata index. The presence of striated periclinal wall on the abaxial surface of both Ludwigia octovalvis variety brevisepala and Ludwigia octovalvis variety linearis delimit them from the other species with smooth periclinal wall.

Jayeola (2000) reported that the occurrence and distribution of parenchyma cells within the wood, apart from their presence as boundary parenchyma may also serve to distinguish two groups of species. All the species of Ludwigia studied have paratracheal parenchyma cells. Trend from heterogenous to homogenous has been noted as a reliable tool to infer specialization; a primitive position for heterogenous rays and an advanced position for homogenous wood rays have been suggested (Outer and Veenandal, 1997; Folorunso and Awosika, 2013). The rays are largely uniseriate and heterocellular in all the species of Ludwigia except in Ludwigia octovalvis variety brevisepala, L. decurrens B and L. erecta. Multiseriate ray is found only in L. leptocarpa while biseriate rays are observed in $L$. decurrens B, L. erecta, L. hyssopifolia and Ludwigia octovalvis variety linearis, the remaining species have only uniseriate rays. L. leptocarpa recorded the longest ray length while the shortest ray length was recorded in L. hyssopifolia. The mean vessel diameter is highest in Ludwigia octovalvis variety brevisepala and lowest in Ludwigia octovalvis variety linearis. Several quantitative and qualitative characters delimit $L$. decurrens A from $L$. decurrens $\mathrm{B}$ as observed in this study: L. decurrens A has the highest stomata index and mean vessel diameter. Mean vessel diameter in Ludwigia species studied represents an invasive character; the species with higher mean vessel diameter are likely to be more invasive in their habits. The presence of laterocytic and staurocytic stomata, styloids and raphides in L. decurrens $\mathrm{A}$ is diagnostic while in $L$. decurrens B they are absent. Biseriate heterocellular rays are only present in $L$. decurrens B. However, these $L$. decurrens $\mathrm{A}$ and L. decurrens $\mathrm{B}$ are separated from the other species by having medullary bundles which is absent in the remaining Ludwigia species studied.

The study of the leaf epidermal surfaces of Ludwigia revealed a number of important micromorphological characters and these characters exhibit interesting variations that are of significance for identification. These findings support previous studies in some other genera where leaf and stem anatomical characters have been used as a veritable taxonomic tool (Adedeji and Illoh, 2004; Saheed and Illoh, 2010; Akçin and Binzet, 2010; Folorunso and Awosode, 2013).

\section{Conclusion}

This study has provided baseline information on the stem anatomy of the Ludwigia species studied. Additional informations on the foliar anatomy of the species are similarly reported. Diagnostic characters for the delimitation of Ludwigia species have been reported, this is envisaged to facilitate identification and classification of the taxa, and characters that could be invasive are also reported. Despite their environmental plasticity, their leaf and stem anatomical characters are constant.

\section{REFERENCES}

Adedeji O, Illoh HC. 2004. Comparative foliar anatomy of 10 species in the genus Hibiscus Linn. in Nigeria. New Botanists, 31: 147-180.

Akçin OE, Binzet R. 2010. The micromorphological and anatomical properties of Onosma angustissimum Hausskn. \& Bornm. and O. cassium Boiss. (Boraginaceae). Bangladesh Journal of Plant Taxonomy, 17(1): 1-8.

Arzani K, Ghasemi M, Yadollahi A, Hokmabadi, H. 2013. Study of foliar epidermal anatomy of four Pistachio rootstock under water stress. IDESIA (Chile), 31(1): Enero-Abril. 
Burke MJW, Grime JP. 1996. An experimental study of plant community invasibility. Ecology, 77: 776-790.

Dandelot S, Verlaque R, Dutartre A, Cazaubon A. 2005. Ecological, dynamic, and taxonomic problems due to Ludwigia (Onagraceae) in France. Hydrobiologia, 551: 131-136.

Dilcher DL. 1974. Approaches to the identification of angiosperm leaf remains. Botanical Review, 40(1): 1-157.

Dutartre A, Dandelot S, Haury J, Lambert E, Le Goff P, Menozzi M-J. 2004. Les jussies: characterisation des relations entre sites, populations et activites humaines. In: Implications pour la gestion. Rapport intermediaire programme INVABIO, Cemagref, Bordeaux, p. 44.

Folorunso AE, Awosika OS. 2013. Use of wood characters in the identification of Nigerian species of Bignoniaceae. Nigerian Journal of Botany, 26(2): 307324.

Folorunso AE, Awosode OD. 2013. Comparative anatomy of invasive and non - invasive species in the family Asteraceae in Nigeria. International Journal of Biological and Chemical Sciences, 7(5): 1804-1819.

Jayeola AA. 2000. Comparative ecological anatomy of two aggressive weeds in Nigeria: Tithonia diversifolia (Hemsl.) A. Gray and Chromolaena odorata (R.H. King and Schrad. Ex D C) H. Robinson. Bulletin of Science Association of Nigerian, 23: 11-16.

Jayeola AA, Thorpe JR, Adenegan TA. 2001. Macromorphological and micromorphological studies of the West Africa Rhizophora L. Feddes Repertorium, 112(5-6): 349-356.

Kadiri AB, Olowokudejo JD. 2010. Systematic significant of foliar epidermal morphology in the West African species of Ludwigia (Onagraceae). Phytologia Balcanica, 16(1): 57-64.

Metcalfe CR, Chalk L. 1979. Anatomy of the Dicotyledons. (2nd edn, Vol. 1). Clarendon Press: Oxford.

Muller S. 2002. Les espèces végétales invasives en France: Bilan des connaissances et propositions d'actions. Revue d'Ecologie-Terre Vie, 7: 53-69.

Ogundipe OT. 2004. Foliar micromorphology of the species of Blighia konig (Sapindaceae) in West Africa. Nigeria Journal of Botany, 17: 53-61.

Outer RW, Veenendaal WLH. 1997. Wood Anatomy of Uncarina leandrii H. Humb. (Pedaliaceae) and its Relation to Bignoniaceae. I.A.W.A. Bulletin, 4(1): 1983.

Oziegbe M, Julius OF, Oluwaranti A. 2010. Effect of seed age and soil texture on the germination of some Ludwigia species (Onagraceae) in Nigeria. Acta Botanica Croatica, 69(2): 249-257.

Oziegbe M, Faluyi JO. 2011. Reproductive biology of Ludwigia leptocarpa and $L$. adscendens subsp. Diffusa in Ile-Ife, Nigeria. Turkish Journal of Botany, 36: 167-173.

Oziegbe M, Faluyi JO, Azeez SO. 2011. Comparative vegetative and fruit characteristics of seven Ludwigia Linn. species in Nigeria. Nigerian Journal of Botany, 24(2): 219-230.

Pysek P, Jarosik V, Hulme PE, Pergl J, Hejda M. 2012. A global assessment of invasive plants impacts on resident species, communities and ecosystems: the interaction ofimpact measures, invading species' traits and environment. Global Change Biology, 18(5): 1725-1737

Richardson DM, Pysek P, Rejmanek MG, Barbour FD, West CJ. 2000. Naturalization and invasion of alien plants: concepts and definition. Diversity and Distribution, 6: 93-107

Saheed SA, Illoh HC. 2010. A taxonomic study of some species in Cassinae (Leguminosae) using leaf epidermal characters. Notulae Botanica Horti Agrobotanici Cluj, 38(1): 21 - 27.

Verlaque R, Aboucaya A, Fridlender A. 2002. Les xe'nophytes envahissants en France : Ecologie, types biologiques et polyploïdie. Botanica Helvetica, 112: 121-136. 